УДК 378.046-021.68-0047.22

DOI:

Тетяна Горохівська, кандидат педагогічних наук, доцент кафедри педагогіки та інноваційної освіти Національного університету “Львівська політехніка"

\title{
РОЗВИТОК ПРОФЕСІЙНО-ПЕДАГОГІЧНОЇ КОМПЕТЕНТНОСТІ ВИКЛАДАЧІВ ФАХОВИХ ДИСЦИПЛІН ТЕХНІЧНИХ ЗВО В УМОВАХ ПІСЛЯДИПЛОМНОЇ ПЕДАГОГІЧНОЇ ОСВІТИ
}

У статті здійснено теоретичний аналіз післядипломної педагогічної освіти як чинника розвитку професійно-педагогічної компетентності викладачів фахових дисциплін технічних закладів вищої освіти. 3'ясовано зміст дефініиії “післядипломна педагогічна освіта”; запропоновано авторське тлумачення иьього поняття. Охарактеризовано професійну програму підвищення кваліфікації науково-педагогічних працівників “Розвиток професійно-педагогічної компетентності викладача закладу вищої освіти”, яка реалізується викладачами кафедри педагогіки та інновачійної освіти Національного університету “Львівська політехніка" в межах прочесу підвищення кваліфікації.

Ключові слова: професійно-педагогічна компетентність; післядипломна освіта; підвищення кваліфікації; викладач вищзої школи; технічний заклад вищуої освіти; професійний розвиток.

Puc. 1. Лim. 11.

Tetyana Horokhivska, Ph.D.(Pedagogy), Associate Professor of the Pedagogy and Innovative Education Department, Lviv Polytechnic National University

\section{DEVELOPING PROFESSIONAL-PEDAGOGICAL COMPETENCY OF LECTURERS OF PROFESSIONAL DISCIPLINES FROM TECHNICAL UNIVERSITIES UNDER POSTGRADUATE TEACHER EDUCATION}

The article presents a theoretical analysis of postgraduate teacher education as a factor in the development of professional-pedagogical competency of lecturers of professional disciplines from technical universities. It justifies the scientific-pedagogical literature and regulatory documents on the issue of postgraduate education. It clarifies the definition of postgraduate teacher education in the works of Ukrainian and foreign researchers (B. James, A. Kuzminskiy, N. Protasova et al.) and offers the author's interpretation of this concept. It shows that the component of postgraduate education is advanced training, which is seen as the acquisition of new or improvement of previously acquired competencies within a certain professional activity. Also, the article highlights the fact that professional development aims to compensate for gaps in the basic technical or pedagogical training and provide with modern knowledge and technologies. At the same time, it justifies the role of advanced training in the development of professional-pedagogical competency in lecturers of professional disciplines from technical universities. In this regard, it describes a professional programme of advanced training of research and teaching staff. The programme, called "Developing Professional-Pedagogical Competency in Lecturers", is implemented by the Pedagogy and Innovative Education Department at Lviv Polytechnic National University in the context of advanced training of research and teaching staff from this very institution. The article shows that its implementation is aimed at developing the structural components of professional-pedagogical competency of lecturers from technical universities. The author of the article defines these components as follows: cognitive-intellectual, personal-motivational, functionaltechnological, social-communicative and reflexive-regulatory. The article concludes that it is essential to improve the professional-pedagogical competency of lecturers of professional disciplines from technical universities under the reforms in higher education and the development of new types and spheres of professional-pedagogical activity. It is important to note that an effective tool for developing this competency is the system of advanced training, designed to ensure the dynamic development of the educational system in Ukraine.

Keywords: the professional-pedagogical competency; a postgraduate education; advanced training; a lecturer; technical university; professional development.

П остановка проблеми. В сучасних умовах реформування вищої національної освіти проблема розвитку професійнопедагогічної компетентності викладачів фахових дисциплін технічних закладів вищої освіти набуває особливої актуальності. Потреба у вдосконаленні професійно-педагогічної компетентності викладачів технічних ЗВО спричинила появу низки суперечностей між потребою суспільства у підвищенні ефективності професійно-педагогічної компетентності викладачів технічних ЗВО та уповільненими темпами оновлення системи їхньої 
післядипломної педагогічної освіти; між динамічними змінами у професійно-педагогічній діяльності, зумовленими зростанням вимог до конкурентоспроможності та традиційним змістом післядипломної освіти; між об'єктивною потребою цілеспрямованого розвитку професійнопедагогічної компетентності викладачів технічних ЗВО та недостатністю відповідного науковометодичного забезпечення цього процесу у системі післядипломної освіти. Подолання означених суперечностей значною мірою залежить від науково обгрунтованої системи післядипломної освіти науково-педагогічних працівників технічних 3ВО, орієнтованої на сучасні світові та вітчизняні педагогічні тенденції, суб'єкт-суб'єктну взаємодію, націленість на розвиток професійно-педагогічної компетентності педагогів у післядипломній освіті з урахуванням ефективних дидактико-методологічних орієнтацій.

Аналіз основних досліджень і публікацій засвідчує, що особливості післядипломної педагогічної освіти сьогодні є предметом дослідження зарубіжних і вітчизняних науковців й педагогів-практиків. Зокрема, необхідність неперервного професійного розвитку педагогів як процесу самореалізації особистості в умовах допрофесійної, професійної і післядипломної підготовки обгрунтовується у працях В. Андрущенка, I. Зязюна, В. Кременя, Н. Ничкало, В. Семиченко, С. Сисоєвої та ін. Дослідженню етапів становлення та розвитку системи післядипломної освіти, особливостям навчання педагогічних та науково-педагогічних працівників у процесі підвищення кваліфікації в галузі післядипломної освіти присвячено роботи таких авторів, як Л. Даниленко, Г. Єльникова, Н. Журавська, О. Коваленко, В. Крисюк, В. Кузьменко, В. Луговий, В. Олійник, В. Радкевич та ін. Важливі теоретичні положення андрагогічного підходу до проблеми підвищення кваліфікації знаходимо у дослідженнях С. Архіпової, В. Вихрущ, М. Громкової, Н. Протасової, В. Пуцова, Л. Романишиної та ін. Не позбавлена наукової уваги і проблема організації підвищення кваліфікації педагогів технічних закладів освіти. Так, у фокусі наукового розгляду опинилися питання, пов'язані із використанням особистісноорієнтованих педагогічних технологій у процесі підвищення кваліфікації інженернопедагогічних працівників (О. Гура, І. Прокопенко, М. Сибірська та ін.). Можливості післядипломної педагогічної освіти у розвитку професійної, професійно-педагогічної компетентності викладачів закладів вищої освіти означаються у працях В. Введенського, О. Горностаєвої,
С. Демченко, Н. Кузьміної, А. Маркової, В. Семенової та ін. Але незважаючи на те, що кількість досліджень, присвячених розгляду ключових теоретичних положень модернізації системи післядипломної педагогічної освіти, особливостей організації та проведення підвищення кваліфікації педагогічних кадрів, постійно зростає, доводячи поглиблення науковопедагогічної уваги до цього актуального напряму, проблема розвитку професійно-педагогічної компетентності викладачів фахових дисциплін технічних закладів вищої освіти у форматі підвищення кваліфікації в галузі післядипломної освіти до останнього часу не знайшла достатнього наукового обгрунтування.

Мета статті. Здійснення теоретичного аналізу післядипломної педагогічної освіти як чинника розвитку професійно-педагогічної компетентності викладачів фахових дисциплін технічних закладів вищої освіти.

Виклад основного матеріалу. Науковці підкреслюють, що в умовах суттєвої зміни ролі викладача відповідно змінюється спрямування i організаційна структура навчання у системі фахового зростання педагогічних та науково-педагогічних працівників, оцінювання педагогічної ефективності, визначення шляхів удосконалення управління цим процесом [5, 52]. “Сучасний педагог повинен стати носієм цінностей освіти, бути підготовленим до вибору та реалізації різних концепцій в умовах варіативної багаторівневої освіти, до постійної самоосвіти, самовдосконалення, саморозвитку, підвищення рівня професіоналізму” $[9,44]$.

В Україні професійна діяльність науковопедагогічного працівника регулюється Конституцією України та галузевим законодавством, що визначають особливості його конституційноправового статусу. Зокрема, відповідно до ст. 53 Закону України “Про вищу освіту” (2014) [3] науково-педагогічні працівники - це особи, які за основним місцем роботи у закладах вищої освіти провадять навчальну, методичну, наукову (науково-технічну, мистецьку) та організаційну діяльність. Тоді як ст. 55 зазначає, що посади науково-педагогічних працівників (зокрема, викладача) можуть займати особи, які мають науковий ступінь або вчене звання, а також особи, які мають ступінь магістра. Науково-педагогічні працівники зобов'язані забезпечувати викладання на високому науково-теоретичному i методичному рівні, провадити наукову діяльність; підвищувати професійний рівень, наукову кваліфікацію; дотримуватись норм педагогічної етики, моралі; дотримуватися у науковій діяльності і освітньому процесі академічної 
РОЗВИТОК ПРОФЕСІЙНО-ПЕДАГОГІЧНОЇ КОМПЕТЕНТНОСТІ ВИКЛАДАЧІВ ФАХОВИХДИСЦИПЛІН ТЕХНІЧНИХЗВО В УМОВАХПІСЛЯДИПЛОМНОЇ ПЕДАГОГІЧНОЇ ОСВІТИ

доброчесності (ст. 58, [3]). Водночас специфіка фахових дисциплін вимагає від викладача технічного 3ВО: глибоких техніко-технологічних, економічних знань; знань тенденцій розвитку галузі виробництва; володіння методами і формами технічної творчості; здатності управляти сучасним устаткуванням і технікою; обізнаності у науково-технічних, політехнічних основах виробництва.

Практика доводить, що у технічному закладі вищої освіти у функціоналі, наприклад, викладача української мови і викладача технологій зварювального виробництва відсутні великі відмінності, окрім тієї, до якого циклу навчального плану належить ця дисципліна. Це означає, що викладач фахової дисципліни - педагог, який викладає навчальні дисципліни циклу професійної підготовки, безпосередньо пов'язаних 3 майбутньою професійною діяльністю студента. Отже, незалежно від специфіки дисципліни (цикл загальної підготовки, цикл професійної підготовки), він здійснює свою професійно-педагогічну діяльність відповідно до посадової інструкції викладача, старшого викладача, доцента, професора. Відмінність складають лише мета, структура і зміст професійно-педагогічної діяльності, адже викладач фахових дисциплін технічного закладу вищої освіти здійснює професійну підготовку студента і від рівня його професійно-педагогічної компетентності залежить якість і конкурентоздатність майбутнього спеціаліста.

Зазначимо, що сьогодні стратегія і тактика реалізації післядипломної освіти педагогічних кадрів окреслена у низці нормативно-правових документів, таких як закони України “Про освіту” (2017), "Про вищу освіту" (2014), Постанова Кабінету Міністрів “Порядок підвищення кваліфікації педагогічних і науково-педагогічних працівників" (2019), Національна доктрина розвитку освіти України у XXI ст. (2002), Національна доповідь про стан і перспективи розвитку освіти в Україні (2016). Водночас на виконання Указу президента України "Про національну стратегію розвитку освіти України на період до 2021 року” (2013) наказом МОН України була затверджена галузева Концепція розвитку неперервної педагогічної освіти (2013), яка передбачала вдосконалення структури післядипломної освіти викладачів; забезпечення якості освіти на всіх рівнях, відповідно до світових та європейських стандартів; реалізацію інтеграції науки і практичної педагогічної діяльності [7]. Актуальність розроблення і прийняття цієї Концепції були зумовлені потребою:
- забезпечення якісного оновлення методології, змісту і технологій перепідготовки та підвищення кваліфікації кадрів для системи освіти на основі поєднання цілісного педагогічного процесу 3 науковими дослідженнями;

- врахування позитивного вітчизняного світового педагогічного досвіду та досягнення загальноприйнятих міжнародних освітніх стандартів;

- запровадження ефективного новаторського підходу до реалізації прогресивних теорій i технологій навчання;

- оновлення та узгодження змісту усіх складових системи підвищення кваліфікації, що передбачались освітніми стандартами.

Варто зазначити, що у Національній доктрині розвитку освіти України у ХХІ ст. (2002) серед ключових проблем визначено необхідність професійного вдосконалення педагогічних працівників, розвиток конкурентоспроможної системи закладів освіти, які здійснюють перепідготовку та підвищення кваліфікації, розробку та впровадження державних стандартів післядипломної педагогічної освіти [8].

Аналіз педагогічної літератури дає підставу стверджувати, що сьогодні в наукових вітчизняних і зарубіжних дослідженнях відсутнє однозначне визначення змісту дефініції “післядипломна педагогічна освіта”. Наприклад Н. Протасова, я розглядає це поняття як “систему навчання та розвитку фахівців 3 вищою освітою, що відбувається у спеціалізованих навчальних закладах засобами самоосвіти та керується державними стандартами до фаху певних рівнів кваліфікації відповідно до вимог суспільноекономічного та науково-технічного прогресу" [6, 23]. Водночас А. Кузьмінський трактує досліджуване поняття як спеціальну освітню діяльність, що забезпечує розвиток та постійне збагачення творчого потенціалу педагога [4]. Б. Джеймс пропонує інше розуміння - широкий спектр заходів, за допомогою яких педагоги можуть розширити особистісну освіту, розвинути власну професійну компетентність і покращити розуміння педагогічних принципів і технологій [11, 15]. Ми вважаємо за доцільне запропонувати тлумачення поняття “післядипломна педагогічна освіта" як необхідної складової неперервної педагогічної освіти викладачів, що здійснюється на основі вільного вибору форм підвищення кваліфікації, основною метою яких є розвиток професійно-педагогічної компетентності відповідно до вимог сучасного освітнього простору.

Зазначимо, що як компонент неперервної 


\section{РОЗВИТОК ПРОФЕСІЙНО-ПЕДАГОГІЧНОӤ КОМПЕТЕНТНОСТІ ВИКЛАДАЧІВ ФАХОВИХ ДИСЦИПЛІН ТЕХНІЧНИХ ЗВО В УМОВАХ ПІСЛЯДИПЛОМНОЇ ПЕДАГОГІЧНОЇ ОСВІТИ}

педагогічної освіти післядипломна педагогічна освіта виконує низку функцій, як-от: компенсаційну (можливість здобуття педагогами додаткової освіти); адаптувальну (пристосування педагогів до змін та нововведень у соціально-економічному, освітньому, виробничому середовищі); розвивальну (підтримка всебічного розвитку особистості у післядипломний період шляхом збагачення і оновлення знань, умінь та навичок) $[2,682]$. При цьому В. Введенський вказує на те, що цілі вищої і післядипломної педагогічної освіти різняться. Так, педагогічні заклади вищої освіти “несуть відповідальність за засвоєння історично сформованих, усталених професійних знань та умінь", тоді як курси підвищення кваліфікації-за засвоєння актуальних та інноваційних професійних компетентностей $[1,51]$. Виходячи з вищезазначеного, можна стверджувати, що метою післядипломної педагогічної освіти, з одного боку, є задоволення потреб науково-педагогічних працівників у професійному та особистому зростанні, а з іншого - забезпечення потреб закладів вищої освіти у кваліфікованих педагогічних кадрах з високим рівнем культури і професійно-педагогічної компетентності, здатних мотивовано і відповідально кваліфікації у відповідність до поточних і перспективних потреб системи освіти;

- формування змісту навчання з урахуванням цільового спрямування, посадових обов'язків викладачів, попередньо здобутої освіти, досвіду професійно-педагогічної діяльності, індивідуальних інтересів і потреб науково-педагогічних працівників;

- застосування сучасних інноваційних технологій, які передбачають диференціацію та індивідуалізацію навчання;

- розробка та постійне удосконалення змісту післядипломної освіти;

- залучення професорсько-викладацьких i наукових кадрів, галузевої та академічної науки, провідних фахівців-практиків до навчального процесу.

Означений підхід знаходить реалізацію у діяльності кафедри педагогіки та інноваційної освіти Національного університету “Львівська політехніка" в рамках виконання професійної програми підвищення кваліфікації науковопедагогічних працівників "Розвиток професійнопедагогічної компетентності викладача закладу вищої освіти" (рис. 1).

\begin{tabular}{|c|c|}
\hline \multirow{4}{*}{$\begin{array}{c}\text { Професійна } \\
\text { програма } \\
\text { “Розвиток } \\
\text { професійно- } \\
\text { педагогічної } \\
\text { компетентност } \\
\text { і викладача } \\
\text { закладу вищої } \\
\text { освіти” }\end{array}$} & Блок 1. Сучасні аспекти розвитку педагогіки XXI ст. \\
\hline & Блок 2. Інформаційні комп’ютерні педагогічні технології в освіті \\
\hline & $\begin{array}{c}\text { Блок 3. Методичні особливості викладання дисциплін у закладі вищої } \\
\text { освіти }\end{array}$ \\
\hline & $\begin{array}{c}\text { Блок 4. Психолого-педагогічні основи діяльності викладача закладу } \\
\text { вищої освіти }\end{array}$ \\
\hline & $\begin{array}{c}\text { Блок 5. Юридично-правові аспекти педагогічної діяльності викладача } \\
\text { закладу вищої освіти }\end{array}$ \\
\hline
\end{tabular}

Рис. 1. Структура професійної програми підвищення кваліфікації науково-педагогічних працівників

виконувати посадові функції, впроваджувати в освітній процес інноваційні процедури.

Притому післядипломна педагогічна освіта має бути спрямована на: збагачення знань (предметних, методичних, психологопедагогічних); розвиток мотивації до творчої діяльності; впровадження досягнень психологопедагогічних наук і врахування особливостей їх реалізації у практиці 3ВО; поширення перспективного педагогічного досвіду. Серед завдань системи післядипломної освіти викладачів технічних ЗВО основними є такі:

- приведення обсягів та змісту підвищення
Окреслені програмні результати спрямовані на розвиток взаємопов'язаних структурних компонентів професійно-педагогічної компетентності викладачів технічних 3ВО, яку ми у своєму дослідженні визначаємо як складне, інтегративне, професійно-особистісне утворення, що характеризує сукупність ціннісно-мотиваційних ресурсів, систему професійно важливих якостей $і$ здібностей особистості, комплекс психологопедагогічних і предметних знань, професійні уміння, комунікативний досвід і досвід самопізнання, відображає готовність до саморозвитку, забезпечує успішну реалізацію 


\section{РОЗВИТОКПРОФЕСІЙНО-ПЕДАГОГІЧНӦ̈ КОМПЕТЕНТНОСТІ ВИКЛАДАЧІВ ФАХОВИХ ДИСЦИПЛІН ТЕХНІЧНИХ ЗВО В УМОВАХПІСЛЯДИПЛОМНОЇ ПЕДАГОГІЧНОЇ ОСВІТИ}

професійно-педагогічної діяльності. До таких компонентів відносимо:

- пізнавально-інтелектуальний - грунтується на глибоких професійних знаннях, які забезпечують варіативність, оптимальність і ефективність побудови освітнього процесу;

- особистісно-мотиваційний - зрілість всієї системи особистісних якостей, цінностей і мотивів викладача, які продуктивно реалізуються у професійно-педагогічній діяльності;

- функціонально-технологічний - діяльність, спрямована на продуктивну реалізацію освітнього процесу, що передбачає розвиток груп умінь, які співвідносяться 3 відповідними функціями професійно-педагогічної діяльності: організаційні (мобілізаційні, інформаційні, розвивальні, орієнтаційні); дослідницькі; інтелектуальні; креативні; предметно-методичні; проєктувальноконструктивні (діагностичні, аналітичні, прогностичні, проектувальні);

- соціально-комунікативний - здатність організовувати продуктивну взаємодію зі студентами і колегами в системі педагогічних (професійних, ділових) та міжособистісних відносин;

- рефлексивно-регулятивний - наявність у викладача умінь управляти власною поведінкою (регулятивна складова) шляхом осмислення ним підстав власних дій та вчинків (рефлексивна складова).

При цьому форми і методи роботи з реалізації означеної професійної програми підвищення кваліфікації викладачів передбачають, поряд із традиційними формами та методами, застосування активних, інтерактивних методів навчання науково-педагогічних працівників. До таких необхідно віднести: обмін досвідом; аналіз конкретних професійно-педагогічних ситуацій; тренінги (соціально-комунікативні; соціальнопсихологічні; розвитку професійно-педагогічних умінь і навичок); ділові ігри (проблемно-діяльнісні; моделювання); аукціони педагогічних ідей; дискусії; “круглі столи”; диспути [10, 89].

Висновки. Здійснений теоретичний аналіз післядипломної педагогічної освіти як чинника розвитку професійно-педагогічної компетентності викладачів фахових дисциплін технічних 3ВО дає підставу стверджувати: післядипломна педагогічна освіта впливає на стан і розвиток соціальноекономічної, технологічної і культурної сфер суспільства двічі: спочатку якістю підготовки власне викладачів фахових дисциплін технічних закладів вищої освіти, а потім - рівнем знань і навичок підготовлених ними випускників технічних 3ВО; сучасна післядипломна педагогічна освіта - це багатофункціональний та відкритий процес неперервної педагогічної освіти, що має свої функції, зміст, форми і методи; результатом неперервної освіти викладачів технічних 3ВО в умовах післядипломноӥ педагогічної освіти має стати високий рівень їх професійно-педагогічної компетентності, яка передбачає не тільки знання традиційних та інноваційних форм, методів, технологій і методик, але й готовність до їх доцільного використання в організації освітнього процесу технічного ЗВО.

Перспектив подальших наукових розвідок полягають у розгляді методичних засад розвитку професійно-педагогічної компетентності викладачів фахових дисциплін технічних закладів вищої освіти в процесі підвищення їхньої кваліфікації у системі післядипломної педагогічної освіти.

\section{ЛІТЕРАТУРА}

1.ВведенскийВ.Н.Моделированиепрофессиональной компетентности педагога. Педагогика. 2003. № 10. C. $51-55$.

2. Енциклопедія освіти / гол. ред. В.Г. Кремень. Київ: Юрінком Інтер, 2008. 1024 с.

3. Закон України Про вищу освіту. Відомості Верховної Ради, 2014, № 37-38, ст. 2004. URL: https://zakon.rada.gov.ua/laws/show/1556-18\#Text.

4. Кузьмінський А.І. Організаційно-педагогічні основи безперервної освіти педагогічних кадрів: автореф. дис. ... канд. пед. наук: 13.00.01. Київ, $1997.24 \mathrm{c}$.

5. Олійник В.В. Наукові основи управління підвищенням кваліфікації педагогічних працівників профтехосвіти: монографія. Київ: Міленіум, 2003. $594 \mathrm{c}$.

6. Протасова Н.Г. Післядипломна освіта педагогів: зміст, структура, тенденції розвитку. Київ: Шкільний світ, 1998. 176 с.

7. Про затвердження Галузевої концепції розвитку неперервної педагогічної освіти : Наказ Міністерства освіти і науки України від 14.08.2013 p. № 1176. Вища школа. 2013. № 9. С. 103-113.

8. Про Національну доктрину розвитку освіти. Указ Президента України № 347/2002 від 17 квітня 2002 p. URL: http://www.zakon4.rada.gov.ua/laws/ show/347/2002.

9. Теплицька А. Науково-теоретичний аспект професійної компетентності: українська наукова школа. Молодь і ринок. Щомісячний науковопедагогічний журнал. Дрогобич, 2018. № 10 (165). C. 41-46.

10. Управління якістю освіти / В.І. Войтенко, А.О. Лавренюк, Л.М. Малинич, В.В. Мельник, В.В. Гуменюк; за заг. ред. А.О. Лавренюка. 


\section{РОЗВИТОК ПРОФЕСІЙНО-ПЕДАГОГІЧНОЇ КОМПЕТЕНТНОСТІ ВИКЛАДАЧІВ ФАХОВИХ ДИСЦИПЛІН ТЕХНІЧНИХЗВО В УМОВАХПІЛЯДИПЛОМНОЇ ПЕДАГОГІЧНОЇ ОСВІТИ}

Хмельницький: ХОІППО; Кам'янець-Подільський: Абетка-НОВА, 2003. 184 с.

11. Department for Education \& Employment. The English Education System: An overview of structure and policy. London : DEE, 1995. 36 p.

\section{REFERENCES}

1. Vvedenskii, V.N. (2003). Modelirovanie professionalnoi kompetentnosti pedagoga [Modeling professional competence of a teacher]. Pedagogy, Vol. 10, pp. 51-55. [in Russian].

2. Kremen, V.H. (Ed.) (2008). Entsiklopediia osbity [Encyclopedia of education]. Kyiv,1024 p. [in Ukrainian].

3. Law of Ukraine on higher education (2014). Bulletin of the Verkhovna Rada, Vol. 37-38. Available at: https://zakon.rada.gov.ua/laws/show/1556-18\#Text [in Ukrainian].

4. Kuzminskii, A.I. (1997). Orhanizatsiinopedahohichni osnovy bezperervnoi osvity pedahohichnykh kadriv [Organization and pedagogical bases of continuous education of pedagogical staff]. Extended abstract of candidate's thesis. Kyiv, 24 p. [in Ukrainian].

5. Oliinyk, V.V. (2003). Naukovi osnovy upravlinnia pidvyshchenniam kvalifikatsii pedahohichnykh pratsivnykiv proftekhosvity: monohrafiia [Scientific bases of management of advanced training of pedagogical workers of professional education: monograph]. Kyiv, 594 p. [in Ukrainian].
6. Protasova, N.H. (1998). Pisliadyplomna osvita pedahohiv: zmist, struktura, tendentsii rozvytku [Postgraduate education of teachers: content, structure, development trends]. Kyiv, 176 p. [in Ukrainian].

7. Order of the Ministry of Education and Science of Ukraine on approval of the sectoral concept of development of continuing pedagogical education №1176 of 14.08.2013. High school. Vol. 9, pp. 103 113. [in Ukrainian].

8. Decree of the President of Ukraine on the National Doctrine of Education Development № 347/ 2002 of April, 17, 2002. Available at: http:// www.zakon4.rada.gov.ua/laws/show/347/2002 [in Ukrainian].

9. Teplytska, A. (2018). Naukovo-teoretychnyi aspekt profesiinoi kompetentnosti: ukrainska naukova shkola [Theoretical aspects of professional competence: Ukrainian scientific school]. Youth and market. Monthly scientific-pedagogical journal. Drohobych, Vol. 10 (165), pp. 41-46. [in Ukrainian].

10. Voitenko, V.L., Lavreniuk, A.O., Malinich, L.M. \& Melnyk, V.V. (2003). Upravlinnia yakistiu osvity [Management of the quality of education]. Khmelnytskyi; Kamianets-Podilskyi, 184 p. [in Ukrainian].

11. Department for Education \& Employment. The English Education System: An overview of structure and policy. London, 1995. 36 p. [in English].

Стаття надійшла до редакції 22.07.2020

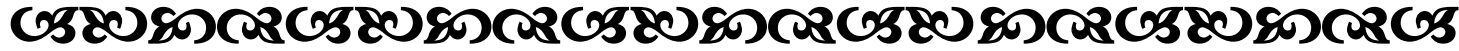

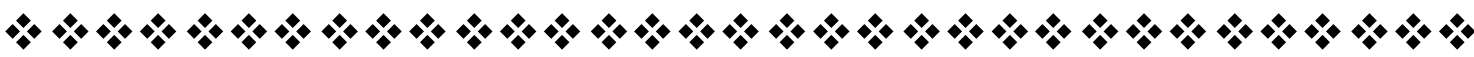

"Будь-яқе навчання людини, є не що інше, якмистецтво сприяти прагненню природи до свого власного розвитку".

$\check{\mathscr{Y} о г а н н ~ Т е н р і х ~ T е с т а л о и и i ~}$ видатний швейцарський педагог-новатор

"Навіть в суспільстві двох чоловік я неодмінно знайду, чому у них повчитися. Їх достоїнства я постараюся наслідувати, а на їх недоліқахсам буду вчитися”.

Конббуиій

давньокитайський фінософб

"Лраия - це одне з найчистіших $i$ найшляхетніших джерел емоиійного стану, радості діяння, творення. Фумқа, що народжена, збуджена, витончена в прачі, стає радісною, оптимістичною".

Василь Сухомлинський педагог, публіиист, письменник, поет

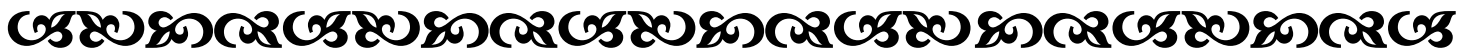

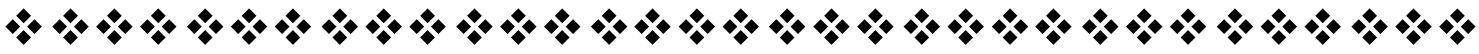

